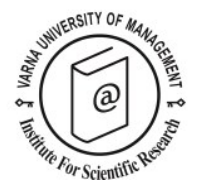

\title{
Differences between short and long break tourists in urban destinations: the case of Barcelona
}

\author{
Jorge Moll-de-Alba ${ }^{1 *}$, Lluís Prats ${ }^{1}$ and Lluís Coromina ${ }^{1}$
}

Received: 21/11/2015 Accepted: 13/05/2016

\footnotetext{
1 University of Girona, Facultat de Turisme, Pl. Josep Ferrater i Móra, 1, 17071 Girona, Spain

* Corresponding author; e-mail: jordi.moll@udg.edu
}

\begin{abstract}
Short break trips in urban destinations are clearly increasing, and this fact has implications for destinations linked to the different length of stay segments. Thus, this paper analyses the duration of the stay in relation to motivation, satisfaction, image, repetition and recommendation of leisure tourists in an urban destination. The main contribution of this article is to highlight the differences and similarities between the behaviours of short and long breakers for the constructs mentioned, not developed until now. The theoretical model is validated using a structural equation modelling methodology. The sample size is 10,953 tourists visiting the city of Barcelona, relevant for its increasing tourism appeal. Results confirm that differences and similarities are found for those tourist segments. By way of example it is worth mentioning that the repeat visits have a negative effect on tourists' recommendation, in particular in the case of long break as compared with short break tourists.
\end{abstract}

(C) 2016 Varna University of Management. All rights reserved

Keywords: length of stay, motivation, satisfaction, image, repeat visits, recommendation

Citation: Moll-de-Alba J., L. Prats and L. Coromina (2016) Differences between short and long break tourists in urban destinations: the case of Barcelona. European Journal of Tourism Research 14 , pp. $29-46$

\section{Introduction}

Two significant trends of the last decade have been the growth of the capacity of attraction of urban centres, with the so-called city break (Dunne, Flanagan \& Buckley, 2011), and the reduction of tourists' stay at the destinations (Alegre, Mateo \& Pou, 2011). Among the factors that have contributed to this increase of tourist activity in Europe we can highlight the phenomenon of low cost travel, the increased number of trips and especially of short trips or short breaks, the changed perception of cities as attractive tourist destinations, and the Internet as a tool for information, planning and organisation of travel, among others (Dunne, Flanagan \& Buckley, 2010).

The economic benefits generated by tourism, the shortening of the duration of the trip and the increased number of trips, have intensified competition between cities. An ever increasing knowledge of markets and consumers reveals 
substantial changes in the tourism consumer. Consequently, destinations that want to be competitive have no choice but to adopt strategies of super-segmentation in order to respond in a personalised manner to the consumers' needs (Raj, 2007). The segmentation criteria applied vary depending on the destination, the market or the positioning desired (Buhalis, 2001), and the principal characteristics of the segments are multiple and do not affect tourism consumption equally.

Thus, one of the research areas that has been studied in depth is the tourism consumer's decision making process, and of all the characteristics studied, the duration of the stay stands out as especially important for the management of tourism destinations (MartínezGarcia \& Raya, 2008). A number of authors, including Alegre \& Pou (2006), have pointed out the importance of the length of stay for tourist destinations. More recently, this particular variable has been the subject of renewed interest (Barros \& Machado, 2010; Ferrer-Rosell, Martínez-Garcia \& Coenders, 2014; Yang \& Zhang, 2015).

This article focuses on short duration travellers (short breakers) and those of long duration (long breakers). In general, short breaks are recognised as a differentiated type of trip. The most widely accepted definition, also used in this article, considers a short break to be a stay between 2 and 4 nights with a non-professional motivation (Murphy, Niininen \& Sanders, 2010). Despite the importance of the length of stay, usually practitioners use short breaks even there being a lack of agreement concerning what a short break is. Nevertheless, a certain amount of research into the short break, such as for example the previous study, has been carried out. Meanwhile, the long break has not been specifically studied as an aspect of city tourism. Therefore, the main contribution of this paper is to explain the differences between the between the two levels of tourist length of stay, an approach that has not been adopted before now.

The study analyses the main characteristics of travellers and their behaviour in the city of Barcelona, with the aim of defining the effect of the length of stay in urban destinations. To accomplish this purpose, nine working hypotheses have been drawn up, and will be tested using structural equations models (SEM), special attention being paid to the comparative lengths of stay of short and long breakers.

The article is divided into different sections. The section that follows reviews the duration of the stay and the five constructs. The model and the methodology used in the study are then introduced, followed by the results obtained and their interpretation. Finally, the conclusions, as well as the limitations of the study and the recommendations and implications deriving from it, are described.

\section{Literature review}

The length of stay: short break vs. long break In the current tourism context, there is evidence of a progressive reduction of the duration of the stay in tourist trips. Among the different variables studied with regard to tourists' behaviour and tourist demand, the duration of stay is, without any doubt, one of the keys to tourism destination management (MartínezGarcia \& Raya, 2008).

Despite its importance, the study of the length of stay is relatively new (Peypoch et al., 2012), as is revealed when Crouch (1994) identified only a few studies where the length of stay was analysed in terms of the number of nights spent at a destination. Since the 90s, the study of the length of stay has generated some controversy and confusion, as it involves segmenting tourist demand. Davies (1990) posits the difficulty of defining short breaks, given the inability of the tourism industry to agree on a definition. Davies considers that short breaks are short trips that include: performance of services of accommodation, transport and event tickets, depending on the aim of the trip. For his part, Edgar (1997) approaches short break trips from the market perspective, and considers them a key market for hotels to increase their profitability using Yield Management techniques. Among tourism agents, there is some confusion concerning the difference between short breaks and the so-called City breaks. Although Dunne, Flanagan \& Buckley (2010) consider it necessary to distinguish between City breaks and short breaks, for the purpose of this article, they will be viewed as a single 
phenomenon, as the case in question is that of tourists to the city of Barcelona. Moreover, another source of confusion is the use of the term short break to refer to day visits or the excursion segment, i.e. without staying the night (Downward \& Lumsdon, 2003; Tsiotsou \& Vasioti, 2006).

In the last decade, the length of stay has been mainly studied with reference to a range of econometric models to explain and predict tourist demand (Barros \& Machado, 2010; Salmasi, Celidoni \& Procidano, 2012; FerrerRosell, Martínez-Garcia \& Coenders, 2014). Other relevant researchers, as for example, Assaf, Barros \& Gil-Alana (2010) using a variety of models they demonstrate different patterns in the short and long-term tourist arriving in Australia; and Yang \& Zhang (2015) using a duration model to identify and predict segments with their different preferences.

In line with these studies, we also consider the length of the stay as the base for segmenting the demand (Neal, 2004). Taking this variable as the segmentation criterion, two separate groups can be identified: trips of short duration or short breaks, and trips of long duration or long breaks. Short breaks are a limited segment as regards knowledge (Tsiotsou \& Vasioti, 2006), while the case of long breaks has not been specifically studied, being considered simply the opposite of short breaks.

This article adopts the definition of the Sustainable Tourism Cooperative Research Centre (STCRC). A short break is "a nonprofessional journey of between one and four nights outside the usual place of residence" (Murphy, Niininen \& Sanders, 2010). This same source recommends "bounding this definition to trips of between two and four nights" to make identification easier. This is the approach which has been adopted in this article.

Globalisation and the evolution of lifestyles have given rise to new travel behaviours, new activities and new forms of tourism, such as urban tourism and tourism consisting of short stays or short breaks. Short breaks are usually closely associated with urban tourism and activities, including sightseeing, shopping, a concentration on leisure activities and shows, and a duration of stay of between two and four nights. Meanwhile urban long breaks still have not been properly explained. This leads us to look into creating our working hypotheses, differentiating the two levels of length of stay. The hypotheses are tested for short and long breaks, their results are compared and the differences between them are explained.

\section{Motivation}

Research into the motivation of tourists has provided knowledge of why people travel, and in turn, enabled us to study travellers' behaviour at the destination. According to Crompton (1979), among individuals who travel for pleasure, two types of motives can be distinguished: the traveller's own personal and internal motives, and those motives related to the destination and its characteristic features. For Baloglu \& Uysal (1996), people travel "pushed" by their internal forces and "pulled" by the external attributes of the destination. The internal forces, called push factors, are intangible or intrinsic to the travellers' individual desires. The external attributes or pull factors are those arising as a result of the destination's capacity of attraction. They consider it proven that a relationship exists between the pull attributes and the push motives for travel. They further segment the demand according to its characteristics and motivations. To the seekers-of-city-life segment, comfort and the variety of the configuration of the city stand out as key. In this way, the destinations that want to attract the urban segment must take special interest in elements such as safety, comfort, cleanliness, the quality of restaurants and the variety and liveliness of the city's activities, among others.

Different studies posit that the motivation can be explained by push and pull factors, and focus on the multimotivational nature of the decision to travel to study tourists' behaviour (Iso-Ahola \& Allen, 1982; Yuan \& McDonald, 1990; Dunne, Flanagan \& Buckley, 2011). However, we must accept limitations in the knowledge of tourists' motivation and behaviour, as for example that motivation has mostly been studied in the western world, that the tourist's nationality has been used as the only substitute for investigating cultural 
differences in the motivation of the journey, among others (Li \& Cai, 2011).

In a competitive environment like the present, it is of special interest for tourism management to study deeply the factors of motivation for tourists, since they help to identify the attributes that must be promoted (Kozak, 2001), and to concentrate on specific segments (MartínezGarcia \& Raya, 2008), as for example, those tourists with more time to travel or with higher tourist expenditure, the cycling tourist (Ritchie, Tkaczynski \& Faulks, 2010), the cruise tourist (Hung \& Petrick, 2011), or in certain contexts, sun and sand destinations (Prebensen, Skallerud \& Chen, 2010; Alegre, Cladera \& Sard, 2011), rural areas (Frochot, 2003), among others. It is also important to understand the relationship of motivation to other elements such as satisfaction or repeat visits. Yoon \& Uysal (2005) established the causal relationship between motivation and satisfaction. On the basis of these studies, we put forward the following hypothesis:

$\mathrm{H}_{1}$ : There is a positive relationship between motivation and satisfaction. The effect of this relationship will vary depending on the duration of the stay.

Yoon \& Uysal (2005) also proved the causal relationship between travel push motivation and destination loyalty, measured both, as repeat visits and as recommendation. Consequently, the following hypothesis is proposed:

$\mathrm{H}_{2}$ : There is a positive relationship between motivation and repeat visits. The effect of this relationship will vary depending on the duration of the stay.

\section{Satisfaction}

Tourist satisfaction is one of the most important elements for the success of destination marketing, and influences both the selection of the destination and the products and services used, and the decision to return (Kozak \& Rimmington, 2000). In general, the most common theories on satisfaction, but which are not exempt from criticism, are based on the expectation-disconfirmation relationship. Satisfaction can be defined as that which consumers do in order to become satisfied.
The model contributed by Oliver (1980) suggests that consumers develop expectations of the product prior to the purchase. Consequently, the consumer compares the result with the expectations. If the result surpasses the expectations, the disconfirmation is positive, which produces satisfaction, and he or she will be predisposed to buy the product again. Oliver \& Swan (1989), in the theory of equity, have suggested that the consumer's satisfaction can be seen as a relationship between the cost, what the consumer spends, and the reward which he/she anticipates.

Among the responses that this theory has received we can highlight some examples of critical research. For instance, Mattila \& O'Neill (2003) consider that the form of service delivery is more important than the result of the service process, and dissatisfaction with the service often occurs simply when guests' perceptions do not meet their expectations. In another study, Yüksel \& Yüksel (2001) believe there remain a number of unresolved operational and conceptual issues concerning this model of customer satisfaction with tourism and hospitality services.

With regard to tourist satisfaction, we can highlight the number of studies that have shown there to be a relationship between satisfaction and other constructs, like loyalty, image, perceived value, quality, and price(Campo \& Yagüe, 2008; Chen \& Tsai, 2008; Yuan \& Jang, 2008; Prebensen, Skallerud \& Chen, 2010; Wang \& Hsu, 2010; Forgas-Coll et al., 2012; Kim et al., 2013; Neuts et al., 2013; Bernini \& Cagnone, 2014). Moreover, recent studies have included experiential aspects like emotions in the research into satisfaction (Mitas et al., 2012; Nawijn et al., 2013; Lin et al., 2014; Charterina \& Aparicio, 2015; Ali, Amin \& Cobanoglu 2016).

In this study, satisfaction is viewed as identical to overall satisfaction (Oliver, 1980). Satisfaction is a temporary state occurring after consumption and reflects how the product or service has fulfilled its purpose (Oliver, 1999).

Empirical evidence demonstrates that satisfaction is an antecedent of loyalty (Oliver, 1999; Oppermann, 2000). Consequently, if the 
level of satisfaction is high, the levels of loyalty will also be high. The degree of loyalty is reflected in the visitor's intention to revisit the destination, repeat visits, and his/her intention to recommend it (Oppermann, 2000). A satisfied tourist is more likely to intend to return to the destination (Martínez-Ruiz, Garau-Vadell \& Campo-Martínez, 2010). Thus, the following hypothesis is proposed:

$\mathrm{H}_{3}$ : There is a positive relationship between satisfaction and repeat visits. The effect of this relationship will vary depending on the duration of the stay.

Besides, a satisfied tourist is more likely to be willing to recommend the destination (Yoon \& Uysal, 2005; Chi, 2011; Prayag \& Ryan, 2012; Marrocu \& Paci, 2013). Therefore, we propose the following hypotheses:

$\mathrm{H}_{4}$ : There is a positive relationship between satisfaction and recommendation. The effect of this relationship will vary depending on the duration of the stay.

\section{Image}

The review of the literature on tourism image shows the multidisciplinary nature of how it has been studied (Gallarza, Gil-Saura \& CalderóGarcía, 2002). The concept of image in relation to tourism is based on the studies by Hunt in 1971. Since then, numerous authors have developed his work by contributing further knowledge of the subject. Hunt (1971) understands the tourism image as "impressions that one or more persons have of a place in which they do not reside". Fakeye \& Crompton (1991) highlight in their definition the concept of overall image, while for Kotler, Haider \& Rein (1994) the image of a destination is a sum of elements like a person's beliefs, ideas, and impressions of a place.

With regard to the different lines of research into image, we can highlight those related to the process of image formation and the different types of image proposed. Gartner (1994) introduced three related components into the formation of the image: cognitive, affective and conative. Baloglu \& McCleary (1999) divide the image into cognitive variables and affective variables, generating what they call an overall image. Stern \& Krakover (1993) in their model of the formation of the image of a city, also confirm that the perceptive / cognitive and affective variables generate the overall image of an urban ambience, forming a composite or general image of the city.

In this article the image of the destination is considered in terms of overall or general image of the city, considering the interactions between the different types of image: that projected by the local industry and that perceived by the consumer (Govers \& Go, 2004). It should also be noted that this study focuses on the image perceived in situ (Galí Espelt \& Donaire Benito, $2005)$, by means of surveys of tourists in the destination.

Another noteworthy element of previous studies that we must bear in mind is the notion that the destination image affects the tourist's perceptions and behaviour. While Camprubí, Guia \& Comas (2009) consider the tourism image to be one of the most important elements in the competitiveness of tourist destinations, for Gartner (1989) and Chi \& Qu (2008), image influences tourists in their selection of the destination. Thus, destinations with a better image will be better considered in the decision processes (Chi \& Qu, 2008), so we can also put forward the following hypotheses:

$\mathrm{H}_{5}$ : There is a positive relationship between motivation and destination image. The effect of this relationship will vary depending on the duration of the stay.

For their part, Lupton \& Court (1997) and Martínez-Ruiz, Garau-Vadell \& CampoMartínez (2010) demonstrate empirically that the image of the destination positively affects the intention to revisit it in the future. Bigné Alcañiz, Sánchez \& Sánchez (2001), Qu, Kim \& Im (2011), Phillips et al. (2013), Zhang et al. (2014) prove the effect of destination image on recommendation: a favourable image held by tourists increases to the likelihood that they will recommend the destination. To verify the relationship between destination image, repeat visits and recommendation, we propose the following working hypotheses: 
$\mathrm{H}_{6}$ : There is a positive relationship between destination image and repeat visits. The effect of this relationship will vary depending on the duration of the stay.

$\mathrm{H}_{7}$ : There is a positive relationship between destination image and recommendation. The effect of this relationship will vary depending on the duration of the stay.

For Chon (1991) and Fakeye \& Crompton (1991), the creation of a positive image of the destination can enhance the tourist's satisfaction. The satisfaction of tourists' needs is associated with an improvement in their experience, and this produces a positive reality. Bigné Alcañiz, Sánchez \& Sánchez (2001), Chi \& Qu (2008), Prayag (2009) and Chen \& Phou (2013) demonstrate causal relationships between destination image and satisfaction. This last point permits us to generate the next hypothesis, based on the fact that if the tourist's stay in the destination has generated high satisfaction, he or she will convey a positive message and image of the destination.

$\mathrm{H}_{8}$ : There is a positive relationship between destination image and satisfaction. The effect of this relationship will vary depending on the duration of the stay.

\section{Repeat visits}

The concept of repeat visits forms part of the consumer's after-purchase behaviour. Martínez-Ruiz, Garau-Vadell \& CampoMartínez (2010) examine repeat visits in depth from two very different perspectives: previous experience and the probability of return. Fakeye \& Crompton (1991), Kozak (2001), Chi (2012), Osti, Disegna \& Brida (2012), Chang, Chen \& Meyer (2013), among others, compare tourists according to whether or not they return. Other researchers have concentrated on the factors influencing repeat visits to a destination (Kozak, 2001; Martínez-Ruiz, Garau-Vadell \& Campo-Martínez, 2010; Meleddu, Paci \& Pulina, 2015). Positive factors such as contact with nature, cleanliness or accessibility, or negative ones like high prices, overdevelopment and overbuilding, among others, are elements of motivation and satisfaction that influence repeat visits (Alegre \& Garau, 2010).
Another line of research into the subject of repeat visits is directly related to the concept of loyalty. Oliver (1999) defines the concept of loyalty as the commitment implied in the transition from a favourable predisposition, affective loyalty, to a repeated purchase commitment, conative loyalty, as a step prior to the act of purchase. In this definition the important element is the repetition of the purchase, and that is one of the most important indicators for measuring the result of marketing strategies (Flavian, Martínez \& Polo, 2001).

Notable in the study of repeat visits and loyalty to destinations is the effort to test the relationships with other concepts like satisfaction, image and motivation. Satisfaction is a determinant of loyalty for Yoon \& Uysal (2005) and Chen \& Phou (2013). Chi \& Qu (2008) prove positive and direct relationships between satisfaction and loyalty, and Kozak, Bigne \& Andreu (2005) prove that satisfaction and the number of previous visits influence intentions to make future visits. For Moniz (2012), repeat visits in tourism are sustained by general satisfaction with the destination and specific satisfaction with certain attributes of the destination.

Furthermore, as mentioned in previous sections, Lupton \& Court (1997), Da Costa Mendes et al. (2010), Martínez-Ruiz, GarauVadell \& Campo-Martínez (2010) demonstrate relationships between the tourism image and the tourist's intention to visit the destination again. Finally, Oppermann (2000) proves that there is evidence that repeat tourists are more inclined to convey their positive experience by recommending the destination.

\section{Recommendation}

Recommendation forms part of the behaviour subsequent to the purchase experience and the use of the service by the consumer. In tourism, recommendation has attracted the attention of researchers mainly because it can be considered one of the best indicators of tourists' loyalty. In this case study, recommendation is considered to be the tourist's intention to transmit his/her travel experience and recommend the destination. Within recommendation we must highlight the importance of word-of-mouth communication, 
(WOM), defined as informal communication between a non-commercial communicator and a receiver, in respect of a brand, a product, an organisation or a service (Anderson, 1998; Prebensen, Skallerud \& Chen, 2010).

We must mention the importance of research to demonstrate the relationships of recommenddation with other constructs. Researchers such as Kozak (2001), Kozak \& Rimmington (2000) and Yoon \& Uysal (2005), consider it proven that satisfaction is an indicator of tourists' intention to recommend to others, so a satisfied tourist is more likely to repeat and recommend his/her positive experience of the destination to family and friends (Chi \& Qu, 2008). Lee, Yoon \& Lee (2007) note the relationships between recommendation and perceived value and satisfaction, while Phillips et al. (2013) prove the effect of destination image, perceived value, attribute and overall satisfaction on WOM recommendation. Finally, for Chi (2012) repeat visitors are more willing to recommend than first-time tourist. This last point allows us to generate the following hypothesis.

$\mathrm{H}_{9}$ : There is a positive relationship between repeat visits and recommendation. The effect of this relationship will vary depending on the duration of the stay.
To sum up, it can be said that recommendation forms part of a broader concept: loyalty. Loyalty obliges destinations to adopt innovative strategies to stimulate the tourist's repeat visits. This highlights the importance of long-term loyalty in the strategies of destinations (Fyall, Callod \& Edwards, 2003).

\section{Structural model proposed}

Figure 1 represents the theoretical causal model proposed. The components of the model correspond to the hypotheses mentioned above. The motivation construct is measured with a binary variable motivation, $0=$ push motivation factors and $1=$ pull factors. Previous studies proved the influence of motivation on satisfaction (Oliver, 1999) and image on satisfaction (Chon, 1991). Therefore, the causal model proposed analyses the relationships of motivation, satisfaction, image, repeat visits and recommendation with the principal contribution of using the length of stay (short break and long break) as tourists' segmentation variable.

\section{Methods \\ Research case}

To test the theoretical model, we selected tourists who visit the city of Barcelona for various reasons. First, Barcelona has become

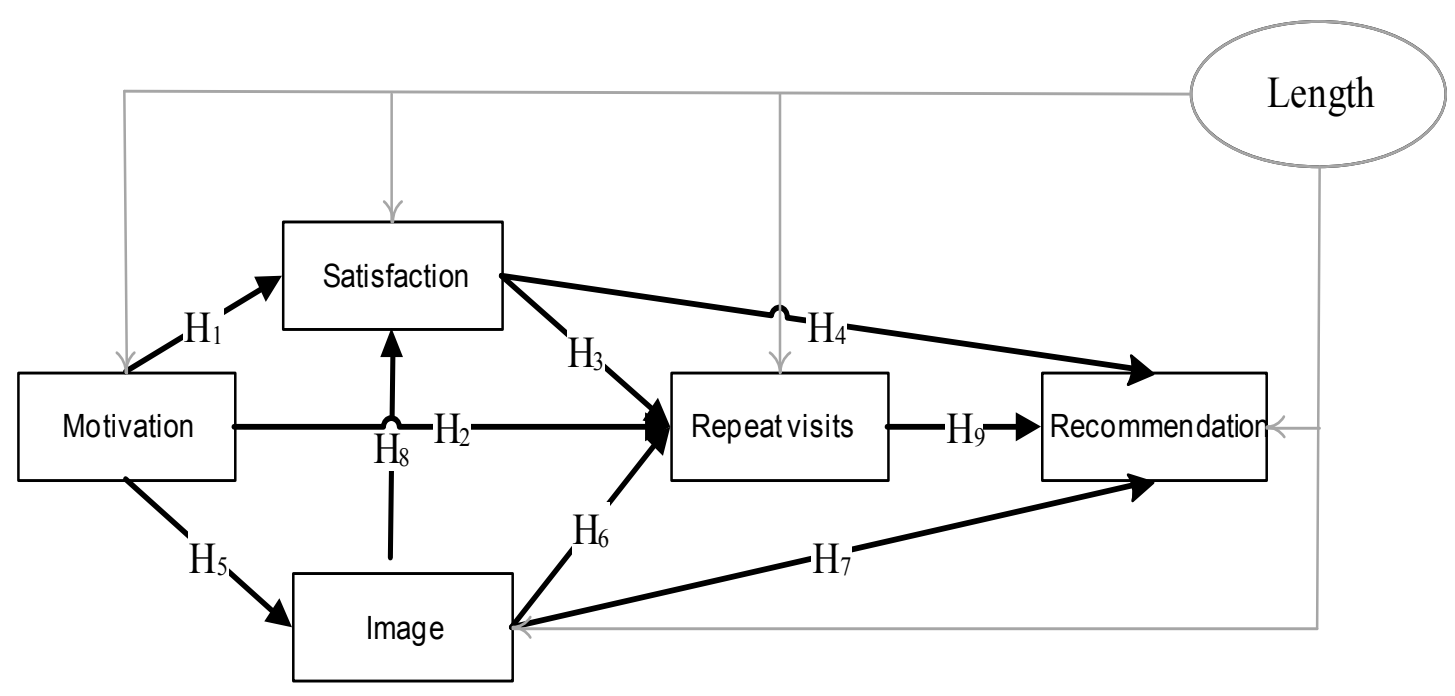

Figure 1. Structural model proposed 
one of the most attractive tourist cities of Europe (Valls et al. 2013). The over 7.4 million tourists who stayed in the city's hotels in 2012 generated more than 15.9 million overnight stays (Turisme de Barcelona, 2012). These figures place Barcelona in the top 6 in the ranking of European tourism cities (ECM, 2013).

Second, the success of the city, thanks to the combination of cultural, urban regeneration and governance strategies, has consolidated a successful model known as the Barcelona Model (Degen \& García, 2012). In this model, image creation and tourism have been key elements, as well as major events like the Olympic Games in 1992 (Casellas, Dot Jutgla \& Pallares-Barbera, 2010). Even so, the dimension of the tourism phenomenon in the city does not correspond to the academic studies carried out. In this field, it is important to highlight the effort made by Turisme de Barcelona, Barcelona Tourist Board, and the Pla Estratègic de Turisme de la Ciutat de Barcelona 2010-2015, as well as the recent work of certain researchers such as Casellas, Dot Jutgla \& Pallares-Barbera (2010), Valls et al. (2013), Forgas-Coll et al. (2012), PalauSaumell et al. (2012), Palou Rubio (2011), among others.

Third, the general lack of knowledge and of studies of specific segments of tourism demand with potentiality, as is the case of short breaks, corroborate the appropriateness of this article, and highlight the importance of new strategies, both for Destination Marketing Organisation (DMO) and for the private sector, prioritising actions on microsegments of demand.

\section{Sample and data gathering}

To evaluate the model of the relationships between the different constructs and the length of stay, we have started from the survey made by Turisme de Barcelona of tourists to the city of Barcelona in the years 2009, 2010 and 2011. We used the results of the survey conducted by trained interviewers through paper and pencil interviews. This survey was carried out in different geographic areas of the city, and at different times. The discriminatory variable allowing us to carry out a multiple-group analysis is the duration of the stay: a first group, called short break, where the number of nights that the tourist has stayed or intends to stay in Barcelona is between 2 and 4 , and a second group called long break, where the number of nights that the tourist has stayed or intends to stay in Barcelona is greater than 4. It must be taken into account that, in keeping with the definitions of the short break, the sample analysed is based on leisure/vacational tourism.

Table 1 shows the variables used to estimate the structural model and to study the

Table 1.Variables used in the structural equations model

\begin{tabular}{|c|c|c|}
\hline Name of the variable & $\begin{array}{l}\text { Scale of } \\
\text { measurement }\end{array}$ & Definition \\
\hline "Push/Pull Motivation" & Binary & $\begin{array}{l}\text { Reason for the decision to come to Barcelona } \\
0=\text { push factors } \\
1=\text { pull factors }\end{array}$ \\
\hline $\begin{array}{l}\text { "Perceived image" } \\
\text { Cronbach's Alpha }=0.73 \\
\text { Broad offer of points of interest } \\
\text { It has a very rich cultural life }\end{array}$ & Metric & $\begin{array}{l}\text { Valuing by Likert scale } \\
1=\text { Totally disagree } \\
5=\text { Totally agree }\end{array}$ \\
\hline "General satisfaction" & Metric & $\begin{array}{l}\text { Valuing by Likert scale } \\
1=\text { minimum } \\
10=\text { maximum }\end{array}$ \\
\hline "Repeat visits" & Metric & $\begin{array}{l}\text { How many times have you visited } B C N \text { in the } \\
\text { last } 10 \text { years? }\end{array}$ \\
\hline "Recommendation" & Metric & $\begin{array}{l}\text { Valuing by Likert scale } \\
1=\text { Certain not to recommend } \\
5=\text { Certain to recommend }\end{array}$ \\
\hline
\end{tabular}


hypotheses posited by the model, its means and standard deviations, divided into short and long breaks, are shown in Table 2.

The tourists were interviewed during the period from 2009 to 2011, the interviews being carried out every day of the week, at different times and locations in the city (hotels and tourist attraction points within the city boundary of Barcelona); this sampling method ensures the quality of data collection. The population consisted of all visitors over 14 years old who stayed in Barcelona less than 30 days. A total of 10,953 tourists have a vacational / leisure

Table 2. Descriptive analysis of the variables used in the structural model

\begin{tabular}{lcccc}
\hline & \multicolumn{2}{c}{ Short break } & \multicolumn{2}{c}{ Long break } \\
\hline & Mean & $\begin{array}{c}\text { Standard } \\
\text { Deviation }\end{array}$ & Mean & $\begin{array}{c}\text { Standard } \\
\text { Deviation }\end{array}$ \\
\hline Pull motivation & 0.176 & 0.381 & 0.158 & 0.365 \\
Many points of interest & 4.483 & 0.554 & 4.429 & 0.578 \\
Very rich cultural life & 4.432 & 0.563 & 4.404 & 0.580 \\
"General satisfaction" & 8.059 & 0.911 & 8.085 & 0.958 \\
"Repeat visits" & 0.732 & 1.623 & 0.711 & 1.541 \\
"Recommendation" & 4.819 & 0.452 & 4.805 & 0.434 \\
\hline
\end{tabular}

Table 3. Selected characteristics of the sample profile

\begin{tabular}{lrrrrrr}
\hline Demographic Characteristics & Short break & $\mathbf{( \% )}$ & $\begin{array}{r}\text { Long } \\
\text { break }\end{array}$ & $\mathbf{( \% )}$ & Total & (\%) \\
\hline Gender & & & & & & \\
Man & 3599 & 55.04 & 2436 & 55.19 & 6035 & 55.10 \\
Woman & 2940 & 44.96 & 1978 & 44.81 & 4918 & 44.90 \\
Total & 6539 & 100.00 & 4414 & 100.00 & 10953 & 100.00 \\
\hline Age & & & & & & \\
15-17 years & 88 & 1.35 & 70 & 1.59 & 158 & 1.44 \\
18-24 years & 1112 & 17.01 & 746 & 16.90 & 1858 & 16.96 \\
25-34 years & 1811 & 27.70 & 1059 & 23.99 & 2870 & 26.20 \\
35-44 years & 1706 & 26.09 & 1299 & 29.43 & 3005 & 27.44 \\
45-54 years & 1171 & 17.91 & 806 & 18.26 & 1977 & 18.05 \\
55-64 years & 498 & 7.62 & 338 & 7.66 & 836 & 7.63 \\
65 or more years & 153 & 2.34 & 96 & 2.17 & 249 & 2.27 \\
Total & 6539 & 100.00 & 4414 & 100.00 & 10953 & 100.00 \\
\hline Occupation & & & & & & \\
Self-employed/ Own account / & 641 & 9.80 & 527 & 11.94 & 1168 & 10.66 \\
Farmer & 188 & 2.88 & 138 & 3.13 & 326 & 2.98 \\
High executive/ High civil servant & 861 & 13.17 & 379 & 8.59 & 1240 & 11.32 \\
Clerk/ Civil Servant & 2176 & 33.28 & 1502 & 34.03 & 3678 & 33.58 \\
Skilled worker & 1101 & 16.84 & 726 & 16.45 & 1827 & 16.68 \\
Worker in other field & 243 & 3.72 & 154 & 3.49 & 397 & 3.62 \\
Retired & 242 & 3.70 & 190 & 4.30 & 432 & 3.94 \\
Housewife & 897 & 13.72 & 704 & 15.95 & 1601 & 14.62 \\
Student & 116 & 1.77 & 48 & 1.09 & 164 & 1.50 \\
Unemployed & 74 & 1.13 & 46 & 1.04 & 120 & 1.10 \\
$\quad$ Others & 6539 & 100.00 & 4414 & 100.00 & 10953 & 100.00 \\
Total & & & & & & \\
Nationality & 788 & 12.05 & 285 & 6.46 & 1073 & 9.80 \\
Spanish & 752 & 11.50 & 352 & 7.97 & 1104 & 10.08 \\
French & 734 & 11.22 & 370 & 8.38 & 1104 & 10.08 \\
British & 721 & 11.03 & 422 & 9.56 & 1143 & 10.44 \\
Italian & 486 & 7.43 & 285 & 6.46 & 771 & 7.04 \\
German & 438 & 6.70 & 463 & 10.49 & 901 & 8.23 \\
USA & 2620 & 40.07 & 2237 & 50.68 & 4857 & 44.34 \\
Others & 6539 & 100.00 & 4414 & 100.00 & 10953 & 100.00 \\
Total & & & & & &
\end{tabular}


motivation, and have stayed in Barcelona two or more nights. Table 3 shows the sample distribution for short breaks and long breaks.

Table 4 shows the characteristics of the trip for short and long break tourists in the city of Barcelona. The results indicate distinctive aspects of the short break segment. For example, they show a preference for staying in hotels. Another distinctive characteristic is that the percentage of repeaters among short break tourists is higher.

\section{Data analysis}

The data analysis was performed in two different stages. First, an exploratory analysis of the variables was done with SPSS 19. This analysis was carried out in order to identify the dimension of the push and pull motivation factors: satisfaction, image, recommendation and repeat visits. The relationships between motivation, satisfaction, image, repeat visits and recommendation were empirically tested using structural equation models (SEM) with Mplus 7. The multiple-group analysis analyses

Table 4. Selected characteristics of the trip

\begin{tabular}{lrrrrrr}
\hline Characteristics of the trip & Short break & $\mathbf{( \% )}$ & $\begin{array}{r}\text { Long } \\
\text { break }\end{array}$ & (\%) & Total & (\%) \\
\hline Accommodation & & & & & & \\
$\quad$ Hotel & 3999 & 61.16 & 2218 & 50.25 & 6217 & 56.76 \\
Boarding house & 910 & 13.92 & 264 & 5.98 & 1174 & 10.72 \\
Apartment, rented house & 282 & 4.31 & 805 & 18.24 & 1087 & 9.92 \\
$\quad$ Hostel, student residence & 769 & 11.76 & 499 & 11.30 & 1268 & 11.58 \\
$\quad$ Friends' house & 544 & 8.32 & 626 & 14.18 & 1170 & 10.68 \\
$\quad$ Cruise & 34 & 0.52 & 0 & 0.00 & 34 & 0.31 \\
$\quad$ Other & 1 & 0.02 & 2 & 0.05 & 3 & 0.03 \\
Total & 6539 & 100.00 & 4414 & 100.00 & 10953 & 100.00 \\
\hline Mean Length of stay & & & & & & \\
$\quad$ Nights & 3.12 & & 7.28 & & & \\
\hline Repeat visit & & & & & & \\
No, 1st visit & 3977 & 61.60 & 2823 & 64.54 & 6800 & 62.79 \\
$\quad$ Yes, 2nd visit & 1528 & 23.67 & 838 & 19.16 & 2366 & 21.85 \\
$\quad$ Yes, 3rd or more visits & 951 & 14.73 & 713 & 16.30 & 1664 & 15.36 \\
Total & 6456 & 100.00 & 4374 & 100.00 & 10830 & 100.00 \\
\hline
\end{tabular}

Table 5. Push and pull motivation factors

\begin{tabular}{|c|c|c|c|}
\hline Push Factors & $(\%)$ & Pull Factors & $(\%)$ \\
\hline Vacations/ Rest & 55.14 & I like the city & 36.92 \\
\hline Desire to know the city & 12.74 & Architecture and monuments & 16.02 \\
\hline To visit Spain & 5.12 & Good prices for travelling / low cost offer & 7.69 \\
\hline Friends live here & 4.54 & Much to visit/see & 6.76 \\
\hline Family live here & 4.04 & Gaudí & 6.23 \\
\hline Studies & 2.53 & It's interesting & 4.25 \\
\hline For its fame and reputation & 2.28 & Culture & 4.14 \\
\hline Revisit the city & 1.60 & Atmosphere & 3.84 \\
\hline For amusement & 1.49 & Climate & 3.79 \\
\hline Never visited Barcelona & 1.39 & Watch football match & 2.85 \\
\hline Accompanying parents & 1.36 & Beach & 1.86 \\
\hline It's been recommended & 1.36 & Cosmopolitan & 1.40 \\
\hline Accompanying husband/ wife & 1.35 & History & 1.22 \\
\hline Visiting son/ daughter & 1.12 & Shops and commerce & 0.99 \\
\hline Visiting partner & 0.97 & Big city & 0.99 \\
\hline Medical visit/ Treatment & 0.84 & It's different & 0.29 \\
\hline Honeymoon & 0.66 & Fair & 0.29 \\
\hline Present & 0.63 & Gastronomy & 0.23 \\
\hline End-of-year/course trip & 0.51 & Opera & 0.23 \\
\hline Family sickness & 0.34 & & \\
\hline
\end{tabular}


whether the model is maintained for the levels of the segmentation variable "Length of stay", where the levels short break and long break represent mutually exclusive and independent groups. The structural model was estimated using robust maximum likelihood.

Initially the push and pull factors of the motivation for trip variable were determined according to Baloglu \& Uysal (1996). The classification obtained is shown in Table 5, where the factors are listed in decreasing order of prevalence.

Rest and vacations are the most important push motive for tourists in Barcelona. This travel motive may be related to the motives of evasion or escapism. Iso-Ahola \& Allen (1982) conceptualises this motivation with the concept "avoidance", taking vacations to escape from something or from someone. The results also show that travellers are tired of their usual chores and need to rest / relax through different activities according to their own interests: visiting monuments, attending shows, etc. The second and third most popular motives for taking a trip are related to the desire to know the city and Spain. Among the remaining push factors, we can mention those related to "the strengthening of family relationships". Several participants confirm that the motive for taking a short break is to meet with members of their family or friends, who, for whatever reason, habitually live apart.

Among the principal motivators we can highlight the factor "I like Barcelona" as the most important, followed by "Architecture and monuments", "Much to visit/see", "Gaudi" and
"Culture". The latter are very closely linked with the urban destination of the city of Barcelona. Other factors like "Good prices for travelling / low cost offer", the attraction of activities programmed in the city such as "Watch football match", "Opera", and physical elements of the city like the beach, the shops and commerce or gastronomy, are also mentioned. These factors are complemented by intangible elements such as "the atmosphere", "cosmopolitan", "it's different", etc. The results demonstrate the variety and multimotivational nature of the city of Barcelona.

Push and pull motivation factors, were recoded in a binary variable named motivation, where push factor $=0$, and pull factors $=1$. The results of a $2 \times 2$ contingency table between the choice of push and pull motives with the duration of the stay (short and long break) demonstrate that there is a statistically significant relationship $\left(x^{2}=5.871,1\right.$ degree of freedom, $p$-value $=0.015$ ) between them. That is to say that the motives are not independent of the stay. In general, the results of the pull motives do not seem to be as important, or mentioned as much, as the push motives. At a comparative level, short break tourists are more motivated by pull factors, and those in the long break group by push elements.

\section{Results}

The data have been studied using structural equations models with multiple-group analysis for the model in Figure 1. The multiple-group model of structural equations was analysed for two groups: short break and long break. The results and the degree of support for the different hypotheses are detailed in Table 6.

Table 6. Results of the structural model

\begin{tabular}{|c|c|c|c|c|}
\hline & & & \multicolumn{2}{|c|}{ Short break Long break } \\
\hline $\mathrm{H}_{1}$ & Motivation & $\rightarrow$ Satisfaction & -0.006 & -0.017 \\
\hline $\mathrm{H}_{2}$ & Motivation & $\rightarrow$ Repeat visits & $0.427^{* * *}$ & $0.369^{* * *}$ \\
\hline $\mathrm{H}_{3}$ & Satisfaction & $\rightarrow$ Repeat visits & $-0.123^{* * *}$ & $-0.079 *$ \\
\hline $\mathrm{H}_{4}$ & Satisfaction & $\rightarrow$ Recommendation & $0.080^{* * *}$ & $0.048^{* * *}$ \\
\hline $\mathrm{H}_{5}$ & Motivation & $\rightarrow$ Image & $0.238^{* * *}$ & $0.065^{\star *}$ \\
\hline $\mathrm{H}_{6}$ & Image & $\rightarrow$ Repeat visits & $0.319^{* * *}$ & $0.213^{* *}$ \\
\hline $\mathrm{H}_{7}$ & Image & $\rightarrow$ Recommendation & $0.364^{* * *}$ & $0.312^{* * *}$ \\
\hline $\mathrm{H}_{8}$ & Image & $\rightarrow$ Satisfaction & $0.968^{* * *}$ & $1.061^{* * *}$ \\
\hline $\mathrm{H}_{9}$ & Repeat visits & $\rightarrow$ Recommendation & $-0.009^{*}$ & $-0.029^{* * *}$ \\
\hline
\end{tabular}


For the evaluation of the fit of the model we apply different measures of goodness of fit. SRMR - Standardised Root Mean Square Residual and RMSEA - Root Mean Square Error of Approximation, are considered an acceptable fit if the values of SRMR are 0.09 or less and RMSEA of 0.06 (Chen, 2007). Furthermore, the CFI (Comparative Fit Index) and the TLI (Tucker - Lewis Index) are considered be acceptable indicators of the model if they are higher than 0.90 (Chen, 2007). The evaluation of this measure is combined with the examination of the MI Modification Index, EPC - Expected Parameter Change, and the potential of the test for a possible specification error (Saris, Satorra \& van der Veld, 2009).

Fit measures for the multiple-group model from Table 6 are the following: Chi-square $=94.615$; $12 \mathrm{df}$; $p$-value $=0.000$; RMSEA $=0.037$ with $90 \%$ confidence interval (0.030; 0.044); CFI=0.985; $\quad$ TLI $=0.962 ; \quad$ SRMR $=0.019$. Therefore, the fit of the model is acceptable according to the fit indices and is correctly specified (Saris, Satorra \& van der Veld, 2009).

With regard to the results of the hypotheses we should note:

First, in hypothesis $\mathrm{H}_{1}$ the effect of motivation on the tourist's satisfaction is not significant, so the motivation, push or pull, does not influence satisfaction. That is to say that satisfaction with the destination is the same for the tourists who travel for push motives as for those who travel for pull motives. This effect is not significant for either of the groups, short break or long break.

Second, in hypothesis $\mathrm{H}_{2}$ the effect of motivation on the frequency of repeat visits is statistically significant and positive. The results obtained for this hypothesis show that tourists who travel to the destination for pull motives present more repeat visits. This effect remains significant for the categories of length of stay, though the effect is stronger $(0.427)$ for the short break tourists.

Third, in hypothesis $\mathrm{H}_{3}$ the tourist's satisfaction has a negative effect on repeat visits, so the greater the tourist's general satisfaction, the fewer the repeat visits. In this sense it is worthy of note that the tourists who repeat most times present a lower satisfaction score.

Fourth, in hypothesis $\mathrm{H}_{4}$ the level of satisfaction has a significant positive effect on the level of recommendation. The results show that tourists with a higher satisfaction score present a higher level of personal recommendation. This hypothesis is acceptable both for short breaks and for long breaks. Nevertheless, if we compare the effects according to the duration of the stay they are greater for short breaks than for long breaks.

Fifth, in hypothesis $\mathrm{H}_{5}$ the effect of motivation on the image is positive and significant. This implies that the tourists who have a pull motivation have a higher opinion of the perceived image of the destination. Comparatively we observe that the results for short break tourists are higher (0.238), than for long break tourists $(0.065)$.

Sixth, in hypothesis $\mathrm{H}_{6}$ the effect of the perceived image on repeat visits is statistically significant and positive. The results prove that a higher level of perceived image leads to more repeat visits. Comparing the results, we observe that this effect is significant in both groups, though the effect is greater for short breaks $(0.319)$, than for long breaks $(0.213)$.

Seventh, in hypothesis $\mathrm{H}_{7}$ the effect of the perceived image on recommendation is statistically significant and positive, meaning that a higher level of perceived image leads to a greater intention on the part of tourists to recommend. If we compare the results for the duration of the stay, the effect is significant for both, though greater for short breaks (0.364), than for long breaks (0.312).

Eighth, in hypothesis $\mathrm{H}_{8}$ the effect of the perceived image on the tourist's general satisfaction is statistically significant and positive, implying that the higher the level of the perceived image, the greater the satisfaction with the destination. Comparatively we observe that this effect is always significant, though it is greater for long break tourists than for short break tourists. 
Finally, in hypothesis $\mathrm{H}_{9}$, the effect of repeat visits on recommendation is statistically significant and negative. This result implies that the tourists who repeat least are those who recommend most. In the comparative results by groups, we can observe that the relationship between repeat visits and recommendation is stronger for long break tourists than for the rest.

Of the nine initial hypotheses, only one, $\mathrm{H}_{1}$, is not supported, because the relationships between motivation and satisfaction are not significant for short break tourists or for those on a long break. Short break tourists present a more intense effect or relationship for hypotheses $\mathrm{H}_{2}, \mathrm{H}_{3}, \mathrm{H}_{4}, \mathrm{H}_{5}, \mathrm{H}_{6}$ and $\mathrm{H}_{7}$, while for long break tourists the relationship between constructs is stronger in hypotheses $\mathrm{H}_{8}$ and $\mathrm{H}_{9}$.

\section{Conclusions, implications and recommend- dations}

This paper sheds light on the tourism trends in urban destinations, differentiating between short breakers and long breakers, and on the role that the length of stay plays in those particular destinations. The main conclusion is that both groups, even if they are not poles apart, are different enough to require differentiated attention by the practitioners and managers of destinations. The analysis and the differences highlighted in the results section of this paper seek to increase the awareness of the length of stay among academics and practitioners (Martínez-Garcia \& Raya, 2008; Neal, 2004) with a view to providing new insights for urban destinations.

The findings of this study are mostly consistent with prior studies. Our results confirm the causal relationships between satisfaction and recommendation (Yoon \& Uysal, 2005; Chi, 2011; Prayag \& Ryan, 2012; Marrocu \& Paci, 2013), image and recommendation (Bigné Alcañiz, Sánchez \& Sánchez, 2001; Qu, Kim \& Im, 2011; Phillips et al., 2013; Zhang et al. 2014), image and satisfaction (Bigné Alcañiz, Sánchez \& Sánchez, 2001; Chi \& Qu, 2008; Prayag, 2009; Chen \& Phou, 2013). By contrast, the effect of motivation on satisfaction described by Yoon \& Uysal (2005) is not significant and was not confirmed in our results.
The main differences found between short and long break groups are as follows. The main distinguishing feature among short and long break tourists is the intensity in the relationship between repeat visits and recommendation (H9), significantly lower in the case for short breakers. In the negative relationship between satisfaction and repeatability $(\mathrm{H} 3)$, the intensity of the relationship is considerably lower for long breakers. For this reason, when analysing relations between repeat visits and recommendation, and satisfaction and repeat visits, it is worth considering the length of stay with reference to the short and long break groups. Other distinguishing characteristics of the long break can be found in the result of the relationship between image and repeat visitation (H6) and motivation and image (H5). In both cases the effects of relations vary to a lesser extent, so it is recommendable to pay attention to the length of stay, and if this information is available, to use it in the analysis.

The results presented have three main implications for the adaptation of DMOs. First of all, there is a clear need to adapt the current promotion to the particular features of this consumption pattern of short breakers (Murphy, Niininen \& Sanders, 2010). Nowadays, promotion is more focused on showing all the opportunities for consumption that a tourist has in a destination, or even on promoting a consumer segment in particular regarding the type of tourism in question, such as gastronomy tourism. But these consumption patterns of visiting the destination more often, for shorter periods of time, are not often addressed by DMOs for international tourists. This would be easy to do, since their consumption behaviour is really similar to that of local tourists and visitors.

Secondly, the DMOs should take into consideration the finding that short breakers are more motivated by such pull factors as tourist attractions, the weather, or cultural sites among others, and that long breakers are more motivated by such push factors as escaping or relaxing among others. This has also implications for promotion, image and brand creation, and adaptation to the real consumption patterns of these groups. 
Finally, the relationship between the repeaters and their satisfaction with the destination constitutes a clear finding. Contrary to the previous results (Chi \& Qu, 2008), when increasing the number of visits to the destination, the visitors' satisfaction decreases proportionally. Bearing in mind that one third of visitors to Barcelona are repeaters, DMOs and tourism companies need to better define their products and their general offer to this group, regardless of whether they are short breakers or long breakers.

Still on the subject of repetition, using the finding that as repeat visits increase, the recommendation level decreases, we open the discussion that being to a destination for the first time, probably generates the "I-want-toexplain-it" effect, and the visitor is more eager to actively recommend it. On the other hand, if you have been to a destination several times, you recommend it only if others ask you directly. This is linked to the fact that first timers have as the main information source the recommendation of family and friends. In this scenario, it is assumed that DMOs adopting marketing and promotion measures for recommendation will help to increase the number of first time visitors to the destination.

By the same token, repeaters have a lower satisfaction score. This fact can be linked with the idea that repeaters could experience more things than first timers and they have been in contact with more people and situations within the destination. For some authors the increase of knowledge about the destination generates a reduction of the gap between expectations and reality (Camprubí, Guia \& Comas, 2009).While that might be true for first timers, the results suggest that as the contact with the destination increases, the risk of dissatisfaction also increases.

\section{Limitations and future research}

The study presents some limitations that must be taken into consideration. First, the results correspond to the case analysis of the city of Barcelona. To be able to generalise them, the same study should be applied to several tourist cities. The application of the proposed model to other destinations may provide evidence for extending and generalising the causal relation- ships of the model. Second, this study uses secondary data from an existing survey carried out by the DMO of Barcelona, Turisme de Barcelona. That is to say, both the questions and the study variables present limitations that would permit specific development to produce more precise data. Even so, the data confirm earlier partial studies which follow the same lines, thus showing their validity. Third, satisfaction, repeat visits and recommendation were measured by means of a single question/ variable and the image by means of two. The use of multi-element scales of measurement in future studies would increase the interpretation and prediction of satisfaction, motivation, image, and recommendation. Therefore, for future studies some of the limitations detected in the variables of the survey could be corrected.

Finally, it is important to stress that the data analysed offer the possibility of exploring the length of stay more in depth, especially by exploring and exploiting a subgroup within short breakers, which might be called Micro breaks. We have found evidence relating to European and domestic tourists arriving in Barcelona for a special event or for business purposes, and staying for only one night. The same thing has been observed with nonEuropeans staying for one night while they were doing a Grand Tour around Europe. We believe that this is not only happening in Barcelona, so it could form part of future research debates.

\section{Acknowledgements}

The authors are pleased to acknowledge the support of Turisme de Barcelona, the city of Barcelona Destination Marketing Organisation in providing them with the raw data. The authors assume all responsibility for any lack of accuracy or reliability in their data analysis.

\section{References}

Alegre, J., Cladera, M., Sard, M. (2011) Analysing the influence of tourist motivations on tourist expenditure at a sun-and-sand destination. Tourism Economics, 17(4), 813-832

Alegre, J., Garau, J. (2010) Tourist Satisfaction and Dissatisfaction. Annals of Tourism Research, 37(1), 52-73 
Alegre, J., Pou, L. (2006) The length of stay in the demand for tourism. Tourism Management, 27(6), 1343-1355

Alegre, J., Mateo, S., Pou, L. (2011) A latent class approach to tourists' length of stay. Tourism Management, 32(3), 555-563

Ali, F., Amin, M., Cobanoglu, C. (2016) An Integrated Model of Service Experience, Emotions, Satisfaction, and Price Acceptance: An Empirical Analysis in the Chinese Hospitality Industry. Journal of Hospitality Marketing \& Management, 25(4), 449-475.

Anderson, E.W. (1998). Customer Satisfaction and Word of Mouth. Journal of Service Research, 1, 5-17

Assaf, A.G., Pestana Barros, C., Gil-Alana, L.A. (2010) Persistence in the Short- and Long-Term Tourist Arrivals to Australia. Journal of Travel Research, 50(2), 213229

Baloglu, S., McCleary, K.W. (1999) A model of destination image formation. Annals of tourism research, 26(4), 868-897

Baloglu, S., Uysal, M. (1996) Market segments of push and pull motivations: a canonical correlation approach. International Journal of Contemporary Hospitality Management, 8(3), 32-38

Barros, C.P., Machado, L.P. (2010) The length of stay in tourism. Annals of Tourism Research, 37(3), 692-706

Bernini, C., Cagnone, S. (2014) Analysing tourist satisfaction at a mature and multiproduct destination. Current Issues in Tourism, 17(1), 1-20

Bigné Alcañiz, E., Sánchez, M. I., Sánchez, J. (2001) Tourism image, evaluation variables and after purchase behaviour: inter-relationship. Tourism Management, 22(6), 607-616

Buhalis, D. (2001) The new tourist and consumer. In Wahab, S. and C. Cooper, (eds.) Tourism in the age of Globalisation. London: Routledge

Campo, S., Yagüe, M. J. (2008) Effects of price on tourist satisfaction. Tourism Economics, 14(3), 657-661

Camprubí, R., Guia, J., Comas, J. (2009) La formación de la imagen turística inducida: Un modelo conceptual. Pasos, Revista de Turismo y Patrimonio Cultural, 7, 255270
Casellas, A., Dot Jutgla, E., Pallares-Barbera, M. (2010) Creación de imagen, visibilidad y turismo como estrategias de crecimiento económico de la ciudad. Finisterra, XLV, 153-172

Chang, K. L., Chen, C. M., Meyer, T. J. (2013) A comparison study of travel expenditure and consumption choices between firsttime and repeat visitors. Tourism Management, 35, 275-277

Charterina, J., Aparicio, G. (2015) A comparison of antecedents of satisfaction in city break traveling. Revista Española de Investigación en Marketing ESIC, 19 (2), 71-82.

Chen, C.-F., Phou, S. (2013) A closer look at destination: Image, personality, relationship and loyalty. Tourism Management, 36, 269-278

Chen, C.-F., Tsai, M.-H. (2008) Perceived value, satisfaction, and loyalty of TV travel product shopping: Involvement as a moderator. Tourism Management, 29(6), 1166-1171

Chen, F.F. (2007) Sensitivity of Goodness of Fit Indexes to Lack of Measurement Invariance. Structural Equation Modeling: A Multidisciplinary Journal, 14, 464-504

Chi, C. G. -Q. (2011) Destination Loyalty Formation and Travelers' Demographic Characteristics: A Multiple Group Analysis Approach. Journal of Hospitality \& Tourism Research, 35(2), 191-212

Chi, C. G.-Q. (2012) An Examination of Destination Loyalty: Differences Between First-Time and Repeat Visitors. Journal of Hospitality \& Tourism Research, 3-24

Chi, C. G.-Q., Qu, H. (2008) Examining the structural relationships of destination image, tourist satisfaction and destination loyalty: An integrated approach. Tourism Management, 29(4), 624-636

Chon, K.-S. (1991) Tourism destination image modification process: Marketing implications. Tourism Management, 12(1), 68-72

Crompton, J.L. (1979) An Assessment of the Image of Mexico as a Vacation Destination and the Influence of Geographical Location Upon That Image. Journal of Travel Research, 17(4), 18-23

Crouch, G. I. (1994). The Study of International Tourism Demand: A Review of Findings. 
Journal of Travel Research, 33(1), 12-23

Da Costa Mendes, J., Do Valle, P. O., Guerreiro, M. M., Silva, J. (2010) The tourist experience: Exploring the relationship between tourist satisfaction and destination loyalty. Tourism, 58, 111126

Davies, B. (1990) The economics of short breaks. International Journal of Hospitality Management, 9(2), 103-106

Degen, M., García, M. (2012) The Transformation of the "Barcelona Model": An Analysis of Culture, Urban Regeneration and Governance. International Journal of Urban and Regional Research, 36(5), 1022-1038

Downward, P., Lumsdon, L. (2003) Beyond the demand for day-visits: an analysis of visitor spending. Tourism Economics, 9(1), 67-76

Dunne, G., Flanagan, S., Buckley, J. (2011) Towards a decision making model for city break travel. International Journal of Culture, Tourism and Hospitality Research, 5(2), 158-172

Dunne, G., Flanagan, S., Buckley, J. (2010) Towards an understanding of international city break travel. International Journal of Tourism Research, 12(5), 409-417

ECM (2013) ECM Benchmarking Report - 9th edition: Figures from more than 110, Dijon

Edgar, D.A. (1997) Capacity management in the short break market. International Journal of Contemporary Hospitality Management, 9, 55-59

Fakeye, P.C., Crompton, J.L. (1991) Image Differences between Prospective, FirstTime, and Repeat Visitors to the Lower Rio Grande Valley. Journal of Travel Research, 30(2), 10-16

Ferrer-Rosell, B., Martínez-Garcia, E., Coenders, G. (2014) Package and nofrills air carriers as moderators of length of stay. Tourism Management, 42, 114-122

Flavian, C., Martínez, E., Polo, Y. (2001) Loyalty to grocery stores in the Spanish market of the 1990s. Journal of Retailing and Consumer Services, 8, 85-93

Forgas-Coll, S. et al. (2012) Urban destination loyalty drivers and cross-national moderator effects: The case of Barcelona. Tourism Management, 33(6), 1309-1320

Frochot, I. (2003) A benefit segmentation of tourists in rural areas: A Scottish perspective'. Tourism Management, 26(3), 335-346

Fyall, A., Callod, C., Edwards, B. (2003) Relationship Marketing. Annals of Tourism Research, 30(3), 644-659

Galí Espelt, N., Donaire Benito, J.A. (2005) The social construction of the image of Girona: a methodological approach. Tourism Management, 26(5), 777-785

Gallarza, M., Gil-Saura, I., Calderó-García, H. (2002) Destination Image Towards a conceptual framework. Annals of Tourism Research, 29(1), 56-78

Gartner, W.C. (1994) Image Formation Process. Journal of Travel \& Tourism Marketing, 2(2-3), 191-216

Gartner, W.C. (1989) Tourism Image: Attribute Measurement of State Tourism Products Using Multidimensional Scaling Techniques. Journal of Travel Research, 28(2), 16-20

Govers, R., Go, F. (2004) Cultural identities constructed, imagined and experienced: a 3-gap tourism destination image model. Tourism, 52(2), 165-182.

Hung, K., Petrick, J. F. (2011) Why do you cruise? Exploring the motivations for taking cruise holidays, and the construction of a cruising motivation scale. Tourism Management, 32(2), 386393

Hunt, J.D. (1971) Image: a factor in tourism. Colorado State University

Iso-Ahola, S.E., Allen, J.R. (1982) The Dynamics of Leisure Motivation: The Effects of Outcome on Leisure Needs. Research Quarterly for Exercise and Sport, 53(2), 141-149

Kim, S. H., Cha, J., Singh, A. J., Knutson, B. (2013) A longitudinal investigation to test the validity of the American customer satisfaction model in the U.S. hotel industry. International Journal of Hospitality Management, 35, 193-202

Kotler, P., Haider, D.H., Rein, I. (1994) Mercadotecnia de localidades, México: Diana.

Kozak, M. (2001) Repeaters' behavior at two distinct destinations. Annals of Tourism Research, 28(3), 784-807

Kozak, M., Bigne, E., Andreu, L. (2005) Satisfaction and Destination Loyalty. 
Journal of Quality Assurance in Hospitality \& Tourism, 5(1), 43-59

Kozak, M., Rimmington, M. (2000) Tourist Satisfaction with Mallorca, Spain, as an Off-Season Holiday Destination. Journal of Travel Research, 38, 260-269

Lee, C.-K., Yoon, Y., Lee, S.-K. (2007) Investigating the relationships among perceived value, satisfaction, and recommendations: The case of the Korean DMZ. Tourism Management, 28(1), 204-214

Li, M., Cai, L.A. (2011) The Effects of Personal Values on Travel Motivation and Behavioral Intention. Journal of Travel Research, 51(4), 473-487

Lin, Y., Kerstetter, D., Nawijn, J., Mitas, O. (2014) Changes in emotions and their interactions with personality in a vacation context. Tourism Management, 40, 416424

Lupton, R.A., Court, B. (1997) Customer Portfolio Development: Modeling Destination Adopters, Inactives, and Rejecters. Journal of Travel Research, 36, 35-43

Marrocu, E., Paci, R. (2013) Different tourists to different destinations. Evidence from spatial interaction models. Tourism Management, 39, 71-83

Martínez-Garcia, E., Raya, J.M. (2008) Length of stay for low-cost tourism. Tourism Management, 29(6), 1064-1075

Martínez-Ruiz, M.P., Garau-Vadell, J.B., Campo-Martínez, S. (2010) Factors influencing repeat visits to a destination: The influence of group composition. Tourism Management, 31(6), 862-870

Mattila, A. S., O'Neill, J. W. (2003). Relationships between Hotel Room Pricing, Occupancy, and Guest Satisfaction: A Longitudinal Case of a Midscale Hotel in the United States. Journal of Hospitality \& Tourism Research, 27(3), 328-341

Meleddu, M., Paci, R., Pulina, M. (2015) Repeated behaviour and destination loyalty. Tourism Management, 50, 159171

Mitas, O., Yarnal, C., Adams, R., Ram, N. (2012) Taking a "Peak" at Leisure Travelers' Positive Emotions. Leisure Sciences, 34(2), 115-135
Moniz, A.I. (2012) A dynamic analysis of repeat visitors. Tourism Economics, 18(3), 505517

Murphy, P., Niininen, O., Sanders, D. (2010) Short-Break holidays-A competitive destination strategy. CRC for Sustainable Tourism Pty Ltd. Retrieved from https://www.researchgate.net/publication/ 229044850_Short-break_holidays_a_ competitive_destination_strategy

Nawijn, J., Mitas, O., Lin, $\bar{Y}$., Kerstetter, D. (2013) How Do We Feel on Vacation? A Closer Look at How Emotions Change over the Course of a Trip. Journal of Travel Research, 52(2), 265-274

Neal, J. D. (2004) The Effect of Length of Stay on Travelers' Perceived Satisfaction with Service Quality. Journal of Quality Assurance in Hospitality \& Tourism, 4(34), 167-176

Neuts, B., Romão, J., van Leeuwen, E., Nijkamp, P. (2013) Describing the relationships between tourist satisfaction and destination loyalty in a segmented and digitalized market. Tourism Economics, 19(5), 987-1004

Oliver, R. (1999) Whence Consumer Loyalty? The Journal of Marketing, 63, 33-44

Oliver, R.L. (1980) A cognitive model of the antecedents and consequences of satisfaction decisions. Journal of Marketing Research, 17, 460-469

Oliver, R.L., Swan, J. (1989) Consumer perceptions of interpersonal equity and satisfaction in transactions: a field survey approach. The Journal of Marketing, 53(2), 21-35

Oppermann, M. (2000) Tourism Destination Loyalty. Journal of Travel Research, 39, 78-84

Osti, L., Disegna, M., Brida, J. G. (2012) Repeat visits and intentions to revisit a sporting event and its nearby destinations. Journal of Vacation Marketing, 18(1), 31-42

Palau-Saumell, R., Forgas-Coll, S., SanchezGarcia, J., Prats-Planaguma, L. (2012) Tourist Behavior Intentions and the Moderator Effect of Knowledge of UNESCO World Heritage Sites: The Case of La Sagrada Familia. Journal of Travel Research, 52(3), 364-376

Palou Rubio, S. (2011) Barcelona, destinació 
turística. Promoció pública, turismes, imatges $i$ ciutat (1888-2010). UB Universitat de Barcelona

Peypoch, N., Randriamboarison, R., Rasoamananjara, F., Solonandrasana, B. (2012) The length of stay of tourists in Madagascar. Tourism Management, 33, 1230-1235

Phillips, W. J., Wolfe, K., Hodur, N., Leistritz, F. L. (2013) Tourist Word of Mouth and Revisit Intentions to Rural Tourism Destinations: a Case of North Dakota, USA. International Journal of Tourism Research, 15(1), 93-104

Prayag, G. (2009) Tourists' evaluations of destination image, satisfaction, and future behavioral intentions-the case of Mauritius. Journal of Travel \& Tourism Marketing, 26(8), 836-853

Prayag, G., Ryan, C. (2012) Antecedents of Tourists' Loyalty to Mauritius: The Role and Influence of Destination Image, Place Attachment, Personal Involvement, and Satisfaction. Journal of Travel Research, 51(3), 342-356

Prebensen, N., Skallerud, K., Chen, J. S. (2010) Tourist Motivation with Sun and Sand Destinations: Satisfaction and the Wom-Effect. Journal of Travel \& Tourism Marketing, 27(8), 858-873

Qu, H., Kim, L. H., Im, H. H. (2011) A model of destination branding: Integrating the concepts of the branding and destination image. Tourism Management, 32(3), 465476

Raj, A. (2007) The New Age of Tourism and the New Tourist. Ahmedabad: Faculty Column IndianMBA.com. Retrieved from http://www.indianmba.com/Faculty_Colum n/FC565/fc565.htm

Ritchie, B. W., Tkaczynski, A., Faulks, P. (2010) Understanding the Motivation and Travel Behavior of Cycle Tourists Using Involvement Profiles. Journal of Travel \& Tourism Marketing, 27(4), 409-425

Salmasi, L., Celidoni, M., Procidano, I. (2012) Length of Stay: Price and Income SemiElasticities at Different Destinations in Italy. International Journal of Tourism Research, 14(6), 515-530
Saris, W.E., Satorra, A., van der Veld, W.M (2009) Testing Structural Equation Models or Detection of Misspecifications? Structural Equation Modeling: A Multidisciplinary Journal, 16(4), 561-582

Stern, E., Krakover, S. (1993) The formation of a Composite Urban Image. Geographical Analysis, 25(2), 130-146

Tsiotsou, R., Vasioti, E. (2006) Satisfaction. Journal of Travel \& Tourism Marketing, 20(1), 61-73

Turisme de Barcelona (2012) Estadístiques del Turisme a Barcelona, Barcelona: Turisme de Barcelona

Valls, J., Banchini, S., Falcón, L., Valls Tuñon, G. (2013) Repositioning of Barcelona's Image in the Light of a Redefinition of the Urban Tourism Planning Model. Pasos, Revista de Turismo y Patrimonio Cultural, 11(1), 89-105

Wang, C., Hsu, M. K. (2010) The Relationships of Destination Image, Satisfaction, and Behavioral Intentions: An Integrated Model. Journal of Travel \& Tourism Marketing, 27(8), 829-843

Yang, Y., Zhang, H.-L. (2015). Modeling tourists' length of stay: does one Model fit all? Tourism Analysis, 20(1), 13-23

Yoon, Y., Uysal, M. (2005) An examination of the effects of motivation and satisfaction on destination loyalty: a structural model. Tourism Management, 26(1), 45-56

Yuan, J., Jang, S. (2008) The Effects of Quality and Satisfaction on Awareness and Behavioral Intentions: Exploring the Role of a Wine Festival. Journal of Travel Research, 279-288

Yuan, S., Mcdonald, C. (1990) Motivational determinates of international pleasure time. Journal of Travel Research, 29(1), 42-44

Yuksel, A., Yuksel, F. (2001). The ExpectancyDisconfirmation Paradigm: A Critique. Journal of Hospitality \& Tourism Research, 25(2), 107-131

Zhang, H., Fu, X., Cai, L. a., Lu, L. (2014) Destination image and tourist loyalty: $A$ meta-analysis.Tourism Management, 40, 213-223. 